\title{
Insulin-Like Growth Factor-Binding Protein 6
}

National Cancer Institute

\section{Source}

National Cancer Institute. Insulin-Like Growth Factor-Binding Protein 6. NCI Thesaurus.

Code C17587.

Insulin-like growth factor-binding protein 6 (240 aa, $\sim 25 \mathrm{kDa}$ ) is encoded by the human IGFBP6 gene. This protein plays a role in insulin-like growth factor binding. 